\title{
Potential of Passion (Passiflora Spp.) Fruit in Control of Type II Diabetes
}

\author{
Saravanan Shanmugam ${ }^{1}$, Murugan Rajan ${ }^{2}$, Adriano Antunes de Souza Araújo ${ }^{1}$ and Narendra Narain ${ }^{2 *}$ \\ ${ }^{1}$ Department of Pharmacy, Federal University of Sergipe, Brazil \\ ${ }^{2}$ Laboratory of Flavor and Chromatographic Analysis, Federal University of Sergipe, Brazil \\ Submission: May 11, 2018; Published: May 25, 2018 \\ *Corresponding author: Narendra Narain, Laboratory of Flavor and Chromatographic Analysis, Federal University of Sergipe, CEP 49100-000, Sao \\ Cristóvão -SE, Brazil, Tel/Fax: +5579 31946514; Email: narendra.narain@gmail.com
}

\begin{abstract}
Passiflora is one of the genera of Passifloracea family. Many of Passiflora fruits are edible and its other parts including leaves, seed and peel are used in traditional medicine system. Several Passiflora species are cherished for its pleasant aroma of the fruits which has been exploited by food, pharmaceutical and cosmetics industries. Presently, the main focus of utilizing this fruit is in its consumption as fruit juice or in manufacturing fruit products like juice, jam and jellies. The aim of this review is to present the current state of knowledge and research findings associated with the use of the Passiflora species in the control of type II diabetes.
\end{abstract}

\section{Introduction}

Diabetes is a complex, acute or chronic disease that involves progressive metabolic disorder of glucose metabolism which eventually leads to micro- and macrovascular dearrangements. In diabetes, blood sugar levels get elevated either because of the pancreas which does not produce enough insulin i.e., insulin dependent type I diabetes or cells do not respond to the production of insulin i.e., non-insulin dependent type II diabetes [1]. The islet cells are used to produce insulin in pancreas which gets destroyed by involvement of former in the immune system, no sooner insulin production is terminated. Diabetic complications are a public health problem that is associated with increased morbidity and mortality rates, and in particular, type II diabetes which is increasing worldwide [2]. The prevalence of diabetes has increased in adults and it constitutes a global public health burden. It is predicted that, India, China and USA will have the largest number of people affected with type II diabetes in 2030 [3].

Diabetes can be prevented by absorption of reducing sugar through inhibition of digestive enzymes viz. $\alpha$-amylase and $\alpha$-glucosidase. The $\alpha$-amylase is a prominent enzyme found in the saliva and pancreas. It hydrolyses $\alpha-1$-4-glycosidic linkage on polysaccharide (starch), producing smaller sugar units such as disaccharide (maltose) and glucose [4]. In contrast, mammalian $\alpha$-glucosidase in the mucosal brush border of the small intestine catalyzes polysaccharide into glucose at terminal non-reducing $\alpha$-1-4-glycosidic linkage in small intestine [5]. The products of glucose molecules from the above reactions are absorbed into the intestine wall. Thus, the inhibitors of $\alpha$-amylase and $\alpha$-glucosidase are considered as therapeutic agents in the treatment of diabetes by delaying glucose absorption and consequently diminishing the postprandial blood glucose excursion that occurs in type II diabetes [6]. The management of diabetes demands multiple therapeutic approaches, since it leads to several complications. There are many pharmacological treatments which are used to cure diabetes by different modes of action such as stimulation of insulin release, increase in the number of glucose transporters, inhibition of gluconeogenes is, and reduced absorption of glucose in the intestine [7]. Thus inhibitors can retard the uptake of dietary carbohydrates, suppress postprandial hyperglycemia, and could be useful for treating diabetic patients [8]. Moreover, glycemic control can be achieved by oral agents using $\alpha$ amylase and $\alpha$-glycosidase inhibitors in the prediabetic state of insulin resistance that either interferes with the absorption of glucose or facilitates glucose disposal in peripheral tissues. Thus, inhibition of $\alpha$-amylase and $\alpha$-glucosidases activity is an effective treatment, and it is an alternative method to control type II diabetes [9]. Currently to reduce postprandial hyperglycemia, the $\alpha$-amylase and $\alpha$-glucosidase inhibitors such as acarbose, miglitol, and voglibose are used primarily to interact with the carbohydratedigesting enzymes which delays glucose absorption. However, excessive dose of these drugs causes many side effects and toxicity. 
The search for natural products in the control of diabetes is a conventional and alternative management strategy. The World Health Organization (WHO) recommended that traditional medicinal practice should be encouraged, especially in countries where access to conventional treatment of diabetes exists [10]. Recently, many herbal formulations from Ayurveda and other traditional systems of medicines are widely used in treatment of diabetes and many more are being evaluated for their effectiveness in controlling diabetes [11]. Numerous $\alpha$-glucosidase inhibitors have been extracted from plants, which are of clinical importance [12]. Moreover, polyphenolic compounds from plants have also been reported to be good inhibitors of key enzymes of $\alpha$-amylase and $\alpha$-glucosidase associated with type 2 diabetes and these cause similar effects as of insulin in the utilization of glucose [13]. In our earlier publications, we reported that plant polyphenols function as potent inhibitors of $\alpha$-amylase and $\alpha$-glucosidase enzymes which decrease postprandial blood glucose levels $[14,15]$.

Table 1: Bioactive compounds from various Passiflora species used for anti-diabetic studies.

\begin{tabular}{|c|c|c|c|c|c|}
\hline Passiflora Species & Plantpart Used & Compounds & Eperimental Activity & $\begin{array}{l}\text { Activity Based on } \\
\text { Biological Action }\end{array}$ & Reference \\
\hline P. alata & Leaves & $\begin{array}{l}\text { Vitexin, isovitexin, } \\
\text { isoorientin, }\end{array}$ & $\begin{array}{l}\text { In vivo experimental } \\
\text { type } 1 \text { diabetes } \\
\text { mellitus in NOD mice. }\end{array}$ & $\begin{array}{c}\text { The hot water extract of } \\
\text { plant leaves exhibited } \\
\text { the better inhibition in } \\
\text { the occurrence of type } 1 \\
\text { Diabetes mellitus in NOD } \\
\text { mice. }\end{array}$ & Colomeu et al. [17] \\
\hline P. subpeltata & Fruit pulp & $\begin{array}{c}\text { Protocatechuicacid, } \\
\text { ferulicacid, vanillicacid, } \\
\text { epicatechin, p-coumaricaci, } \\
\text { cinnamicaci, eriodictyoland } \\
\text { quercetin-3-glucoside }\end{array}$ & $\begin{array}{c}\alpha \text {-amylase and } \\
\alpha \text {-glucosidase activity }\end{array}$ & $\begin{array}{c}\text { The maximum inhibition } \\
\text { of } \alpha \text {-amylase and } \\
\alpha \text {-glucosidase was } \\
\text { observed in the fresh } \\
\text { fruit pulp }\left(\mathrm{IC}_{50} \text { of } 18.69\right. \\
\text { and } 32.63 \mu \mathrm{g} / \mathrm{mL} \text {, } \\
\text { respectively). }\end{array}$ & $\begin{array}{c}\text { Saravanan et al. } \\
{[18]}\end{array}$ \\
\hline P. edulis & Peel, seeds & $\begin{array}{c}\text { Passiflin, Isoorientin, } \\
\text { Orientin, Vitexin, isovitexin }\end{array}$ & $\begin{array}{c}\text { STZ induced diabetic } \\
\text { mice in Type II } \\
\text { diabetes mellitus }\end{array}$ & $\begin{array}{l}\text { The ethanolic extracts } \\
\text { of } P \text {. edulis exhibited } \\
\text { anti-diabetic effects, as } \\
\text { well as in streptozotocin } \\
\text { induced diabetic rats by } \\
\text { maintaining their blood } \\
\text { glucose levels }\end{array}$ & $\begin{array}{l}\text { Kandandapani et } \\
\text { al. [26] }\end{array}$ \\
\hline P. ligularis & Fruit pulp & $\begin{array}{l}\text { Ellagic acid, gallic acid, rutin, } \\
\text { kaempferol and caffeic acid }\end{array}$ & $\begin{array}{c}\alpha \text {-amylase and } \\
\alpha \text {-glucosidase activity }\end{array}$ & $\begin{array}{c}\text { The fruit pulp and } \\
\text { extracts demonstrated } \\
\text { potent } \alpha \text {-amylase and } \\
\alpha \text {-glucosidase enzyme } \\
\text { inhibition anti-diabetic } \\
\text { properties }\end{array}$ & $\begin{array}{c}\text { Saravanan \& } \\
\text { Parimelazhagan } \\
{[27]}\end{array}$ \\
\hline P. incarnata & Leaves & $\begin{array}{l}\text { Methanolic extract of leaves, } \\
\text { Chlorogenic acid, hyperosid, } \\
\text { isovetixin, caffeic acid, } \\
\text { quercitin, luteolin, orentin, } \\
\text { rutin, scutelarein, vitexin }\end{array}$ & $\begin{array}{c}\text { STZ induced diabetic } \\
\text { mice in Type II } \\
\text { diabetes mellitus }\end{array}$ & $\begin{array}{l}\text { Tested plant methanolic } \\
\text { extract (at the doses } \\
\text { of } 100 \text { and } 200 \mathrm{mg} / \mathrm{kg}, \\
\text { administrated for } 15 \\
\text { days) showed anti- } \\
\text { diabetic activity in a } \\
\text { streptozotocin-induced } \\
\text { diabetic mouse model, } \\
\text { improving the oral } \\
\text { glucose tolerance, body } \\
\text { weight, urine glucose, } \\
\text { liver glycogen and lipid } \\
\text { profile. }\end{array}$ & Gupta et al. [30] \\
\hline
\end{tabular}

Passion fruit belongs to the genus Passiflora, which comprises about 580 plant species of the family Passifloraceae. Passiflora is the most important genus of the family and is mainly distributed in tropical and temperate regions all over the world [16]. Many phytotherapeutic compounds of this plant play vital roles in neutralizing free radicals in the living cells [17]. Major compounds of Passiflora species with novel functional properties are C-glycosil derivatives such as apigenin and luteolin, vitexin, isovitexin, orientin, schaftoside, 2"-0-rhamnoside and luteolin-7-0-(2-rhamnosylglucoside), quercetin 3- $\beta$-D-glucoside, isoscoparin -2"-0-glucoside. All these compounds present antioxidant activity, leading to the neutralization of free radicals in the cellular level $[17,18]$. In the present review, an attempt is made to evaluate $\alpha$-amylase and $\alpha$-glucosidase enzyme inhibitors along with in vivo experiments performed from the use of Passiflora species to develop 


\section{Current Research in Diabetes \& Obesity Journal}

physiological functional food to treat diabetes. Table 1 presents the data on Bioactive compounds from various Passiflora species used for anti-diabetic studies.

\section{Discussion}

Dietary factors are important forecasters for the risk of obesity and type 2 diabetes diseases. The regular consumption of saturated/animal fat is associated with overweight that, in turn, deteriorates insulin sensitivity and glucose tolerance in humans and experimental animal model. On the other hand, increased intake of fiber-rich foods, fruits, and vegetables as well as limited amounts of total and saturated fats are important elements in the prevention of type 2 diabetes [19]. Moreover, endogenous antioxidants are incapable of preventing oxidative damages which occur in many human ailments associated with diseases such as, cancer, cardiovascular diseases and diabetes. Therefore, our body requires exogenous scavengers which could be obtained from the regular diet, such as vitamins, minerals, carotenoids and polyphenols [20]. Thus the interest in these fruits has increased due to the presence of antioxidants in these foods, which can prevent cellular oxidative stress [21].

Passion fruit is cherished mainly because of its high acidity and strong aroma. It is consumed widely as fresh fruit and is also used to produce industrialized juice and several other fruit products. Worldwide, this plant species has been used extensively in the traditional medicine system as well as in the therapeutic system [22]. Several bioactive compounds present in Passiflora species impart healthy beneficial effects. Many workers report that the co-products of tropical passion fruits contain higher amounts of bioactive compounds including polyphenolic antioxidants, vitamins, minerals, and dietary fiber, which may have positive health effects and contribute to preventing some diseases such as, cancer, cardiovascular diseases and diabetes $[23,24]$.

Isolated flavonoid compounds and the crude extract from the $P$. bogotensis fruit were evaluated for $\alpha$-glucosidase enzyme inhibitory activity against the enzyme obtained from the yeast Saccharomyces cerevisiae [25]. Isolation of C-glycosylflavonoids showed higher $\alpha$-glucosidase enzyme inhibitory activity. Some preliminary suggestions about the structure-activity relationship indicates that the acetyl group in the position C(6") has a favorable and possibly the strongest influence on the inhibitory activity of the $\alpha$-glucosidase enzyme. Thus the authors also suggested that some identified compounds of this plant species have the acetyl group in the $\mathrm{C}\left(3^{\prime \prime}\right)$ and $C\left(4^{\prime \prime}\right)$ position which also leads to higher enzyme inhibitory activity.

The ethanolic extracts of peel and seed of P. edulis (Passifloraceae) fruit attenuate oxidative stress in diabetic rats induced by the streptozotocin (STZ) injection [26]. The authors performed the experiments in vivo animal model. The diabetic animals were treated with 250 and $500 \mathrm{mg} / \mathrm{kg}$ of P. edulis extracts and glibenclamide $0.6 \mathrm{mg} / \mathrm{kg}$ for fifteen days by oral route. The diabetic animals treated with $P$. edulis extracts $(500 \mathrm{mg} / \mathrm{kg})$ showed protective effects against STZ-induced histopathological changes in pancreas. This effect was evidenced by attenuation of leukocyte infiltration and gross morphological changes. A similar effect was observed in the glibenclamide treated diabetic rats. Also the diabetic control rats had impaired blood glucose levels $(10.00-18.00 \mathrm{mmol} / \mathrm{L})$. The blood glucose levels of the $P$. edulis extracts treated diabetic rats were maintained at an ideal condition $(6.00-8.00 \mathrm{mmol} / \mathrm{L})$. In addition ethanolic extract of the fruit significantly reversed the decrease in body weight of the diabetic rats. This result clearly demonstrated the euglycemic property of the extracts by decreasing the high blood glucose level and thus resulting in the maintenance of a normal body weight in diabetic rats.

Pancreatic $\alpha$-amylase, as a key enzyme in the digestive system, is involved in the breakdown of starch into disaccharides and oligosaccharides and finally liberating glucose which is later absorbed into the blood circulation. The inhibition of $\alpha$-amylase enzyme activity of $P$. ligularis fruit pulp and standard drug acarbose was reported in a dose-dependent manner (75-125 $\mu \mathrm{g}$ / $\mathrm{mL}$ ) [27]. Compared with the standard acarbose, the acetone extract of plant sample showed significant inhibition activity (82.56\%). $\alpha$-glucosidase inhibitory activity of different extracts of $P$. ligularis fruit pulp was confirmed. The acetone extract showed the most significant inhibition activity of $75.36 \%$ in a concentration-dependent manner $(75-125 \mu \mathrm{g} / \mathrm{mL})$, which was comparable with the standardacarbose $(79.87 \%)$ effect. These authors also suggested that the synergetic effects of the polyphenolic compounds including gallic acid, caffeic acid, rutin, ellagic acid and kaempferol are the main reason for the maximum enzyme inhibitory activity of the P. ligularis fruit pulp.

Carlos Victor Montefusco Pereira et al. [28] reported the hypoglycemic effects of the leaf extract from Passifloranitida. The hydroethanol leaf extract revealed an in vitro $\alpha$-glucosidase inhibitory activity of $50 \%$ inhibitory concentration $\mathrm{IC}_{50}=6.78 \pm 0.31 \mu \mathrm{g} / \mathrm{mL}$ and $\alpha$-amylase inhibition of $\mathrm{IC}_{50}=93.36 \pm 4.37$. In vivo experiments performed on different saccharide tolerance resulted in significant glycemia control and, with alloxan-diabetic mice, resulted in a decrease of total cholesterol, a hypoglycemic effect, and an antioxidant activity by thiobarbituric acid-reactive substances.

Colomeu et al. [17] reported the antioxidant and anti-diabetic potential of $P$. alata aqueous leaves extract in type 1 diabetes mellitus in non-obese mice (NOD-mice). The consumption of aqueous extract of $P$. alata treated group presented a decrease in diabetes incidence, a low quantity of infiltrative cells in pancreatic islets and an increased glutathione in kidney and liver $(p<0.05)$, when compared with the diabetic and non-diabetic control-groups. GSH levels in mammalian cells were in the range of $0.5-10 \mathrm{mmol} / \mathrm{L}$, and changes in these values may indicate oxidative stress and diseases such as diabetes mellitus. In NOD mice, the treatment with aqueous extract of $P$. alata showed a higher amount of GSH, when compared with the control group. 


\section{Current Research in Diabetes \& Obesity Journal}

The inhibitory activities of $P$. subpeltata fruit pure pulp and the fruit extracts on $\alpha$-amylase and $\alpha$-glucosidase were significantly higher in the acetone extract [18]. The IC50 and inhibition percentage values of fresh pulp were maximum for both $\alpha$-amylase $\left(84.66 \%, \mathrm{IC}_{50}=18.69 \mu \mathrm{g} / \mathrm{mL}\right)$ and $\alpha$-glucosidase $\left(86.89 \%, \quad\right.$ IC $\left._{50}=32.63 \mu \mathrm{g} / \mathrm{mL}\right)$ enzymes in a concentration dependent manner. These results were significantly $(p<0.05)$ comparable with the standard drug, acarbose. The number of the hydroxyl groups on the phenolic and flavonoid compounds especially, on the B ring was closely associated with the inhibitory activity of the $\alpha$-amylase and $\alpha$-glucosidase enzymes [29]. According to this hypothesis, the fresh pulp of the P. subpeltata fruit has 15 phenolic and flavonoid compounds which were identified in this plant species and these may assist in inhibiting the diabetic key enzymes. The compounds viz. protocatechuic acid, ferulic acid, vanillic acid and epicatechin could efficiently involve in the process of key enzymes inhibition. The main reason behind this process might be the many hydroxyl groups present in these compounds [18].

\section{Conclusion}

Modern medicine system and various research groups published the potential and therapeutic effects of extracts obtained from different parts of Passiflora spp., fruit which possesses strong acidic aroma and it plays a vital role in the manufacture of industrial products including fruit juice and fruit jams production. The abundant source of the bioactive molecules of the Passiflora species provide the natural antioxidants and functional ingredients responsible to scavenge the radicals which produces the DNA damages in the cells and organisms to produce various ailments especially, the diabetic and obesity conditions. Based on this and findings of various other reports, it is confirmed that the direct intake of passion fruit supply provide various natural secondary metabolites which regulate the blood glucose levels. Thus passion fruit contributes for nutraceutical applications and in the glucose control management for Type 2 diabetic suffering humans [30].

\section{References}

1. Klein O, Lynge J, Endahl L, Damholt B, Nosek L, et al. (2007) Albuminbound basal insulin analogues (insulin detemir and NN344): comparable time-action profiles but less variability than insulin glargine in type 2 diabetes. Diabetes Obes Metab 9(3): 290-299.

2. Surya S, Salam AD, Tommy DV, Carla B, Kumar RA, et al. (2014) Diabetes mellitus and medicinal plants-review. Asian Pacifc J Trop Dis 4(5): 337 347.

3. Wild S, Roglic G, Green A, Sicree R, King H (2004) Global prevalence of diabetes: estimates for the year 2000 and projections for 2030 . Diabetes Care 27(5): 1047-1053.

4. Aff AF, Kamel EM, Khalil AA, Foaad MA, Fawziand EM, et al. (2008) Purifcation and characterization of $\alpha$-amylase from penicillium olsonii under the effect of some antioxidant vitamins. Global J Biotechnol Biochem 3(1): 14-12.

5. Watcharachaisoponsiri T, Sornchan P, Charoenkiatkul S, Suttisansanee U (2016) The $\alpha$-glucosidase and $\alpha$-amylase inhibitory activity from different chili pepper extracts. Inter Food Res J 23(4): 1439-1445.
6. Kwon YI, Apostolidis E, Shetty K (2007) Evaluation of pepper (Capsicum annuum) for management of diabetes and hypertension. J Food Biochem 31(3): 370-385.

7. Thilagam E, Parimaladevi B, Kumarappan C, Mandal SC (2013) $\alpha$-Glucosidase and $\alpha$-amylase inhibitory activity of Senna surattensis. J Acupunct Meridian Stud 6(1): 24-30.

8. Watanabe J, Kawabata J, Kurihara H, Niki R (1997) Isolation and identification of $\alpha$-glucosidase inhibitors from Tochu-cha (Eucommiaulmoides). Biosci Biotechnol Biochem 61(1): 177-178.

9. Krentz AJ, Bailey CJ (2005) Oral antidiabetic agents: current role in type 2 diabetes mellitus. Drug 65(3): 385-411.

10. (1980) World Health Organization Expert Committee on diabetes mellitus: Second report. World Health Organ Tech Rep Ser 646: 1-80.

11. Mishra R, Shuaib M, Shravan, Mishra PS (2011) A review on herbal antidiabetic drugs. J Appl Pharm Sci 1: 235-237.

12. Yoshikawa M, Murakami T, Yashiro K, Matsuda H (1998) Kotalanol, a potent alpha-glucosidase inhibitor with thiosugar sulfonium sulfate structure, from antidiabetic ayurvedic medicine Salacia reticulata. Chem Pharm Bull (Tokyo) 46(8): 1339-1340.

13. Reddy NVLS, Anarthe SJ, Raghavendra NM (2010) Effect of thermal treatment an phenolic content. J Res Biomed Sci 1(2): 72-75.

14. Shanmugam S, Baby JP, Chandran R, Thankarajan S, Thangaraj P (2016) Maesa indica: a nutritional wild berry rich in polyphenols with special attention to radical scavenging and inhibition of key enzymes, $\alpha$-amylase and $\alpha$-glucosidase. J Food Sci Technol 53(7): 2957-2965.

15. Murugan R, Prabu J, Chandran R, Sajeesh T, Iniyavan M, et al. (2016) Nutritional composition, in vitro antioxidant and anti-diabetic potentials of Breyniaretusa (Dennst.) Alston. Food Sci Human Well 5(1): 30-38.

16. Silvana VFG, Portugala LA, Jeancarlo P, Onildo NJ, Eder JO, et al. (2017) Accelerated solvent extraction of phenolic compounds exploiting a Box-Behnken design and quantification of five flavonoids by HPLCDAD in Passiflora species. Microchem J 132: 28-35.

17. Colomeu TC, Figueiredo D, Cazarin CBB, Schumacher NSG, Marostica MR, et al. (2014) Antioxidant and anti-diabetic potential of Passifloraalata Curtis aqueous leaves extract in type 1 diabetes mellitus (NOD-mice). Int Immunopharmacol 18(1): 106-115.

18. Saravanan S, Isla Alcântara G, Marina D, Bruno dos SL, Adriano Antunes de S, et al. (2018) UHPLC-QqQ-MS/MS identification, quantification of polyphenols from Passiflora subpeltata fruit pulp and determination of nutritional, antioxidant, $\alpha$-amylase and $\alpha$-glucosidase key enzymes inhibition properties. Food Res Inter 108: 611-620.

19. Glaucia CL, Milena MV, Angela GB, Nathalia RV, Dragano, et al. (2016) Passiflora edulis peel intake improves insulin sensitivity, increasing incretins and hypothalamic satietogenic neuropeptide in rats on a high-fat diet. Nutrition 32(7-8): 863-870.

20. Juliana KS, Cinthia BB, Cazarin, Angela GB, Mario MJ (2014) Effects of passion fruit (Passiflora edulis) by product intake in antioxidant status of Wistar rats tissues. LWT -Food Sci Technol 59: 1213-1219.

21. Habib HM, Ibrahim WH (2011) Effect of date seeds on oxidative damage and antioxidant status in vivo. J Sci Food Agric 91(9): 16741679.

22. Rúbia CG, Correa, Rosane M, Peralta, Charles WI, et al. (2016) The past decade findings related with nutritional composition, bioactive molecules and biotechnological applications of Passiflora spp. (passion fruit). Trends Food Sci Technol 58: 79-95.

23. Ayala Zavala JF, Vega Vega V, Rosas Domínguez C, Palafox Carlos H, Villa Rodriguez JA, et al. (2011) Agro-industrial potential of exotic fruit by products as a source of food additives. Food Research International 44(7): 1866-1874. 


\section{Current Research in Diabetes \& Obesity Journal}

24. Viuda Martos M, López Marcos MC, Fernández López J, Sendra E, López Vargas JH, et al. (2010) Role of fibre in cardiovascular diseases: A review. Compr Rev Food Sci Food Safety 9: 240-258.

25. Costa GM, Cardenas PA, Gazola AC, Aragon DM, Castellanos L, et al. (2015) Isolation of C-glycosylflavonoids with a-glucosidase inhibitory activity from Passiflora bogotensis Benth by gradient high-speed counter-current chromatography. J Chromatogr B Analyt Technol Biomed Life Sci 990: 104-110.

26. Kandandapani S, Balaraman AK, Ahamed HN (2015) Extracts of passion fruit peel and seed of Passiflora edulis (Passifloraceae) attenuate oxidative stress in diabetic rats. Chin J Nat Med 13(9): 680-686.

27. Saravanan S, Parimelazhagan $\mathrm{T}$ (2014) In vitro antioxidant antimicrobial and antidiabetic properties of polyphenols of Passiflora ligularis Juss. fruit pulp. Food Sci Human Well 3(2): 56-64.
28. Montefusco Pereira CV, de Carvalho MJ, de Araújo Boleti AP, Teixeira LS, Matos HR, et al. (2013) Antioxidant, anti-inflammatory, and hypoglycemic effects of the leaf extract from Passiflora nitida Kunth. Appl Biochem Biotechnol 170(6): 1367-1378.

29. Liu S, Ai Z, Qu F, Chen Y, Ni D (2017) Effect of steeping temperature on antioxidant and inhibitory activities of green tea extracts against $\alpha$-amylase, $\alpha$ - glucosidase and intestinal glucose uptake. Food Chem 234: 168-173.

30. Gupta RK, Kumar D, Chaudhary AK, Maithani M, Singh R (2012) Antidiabetic activity of Passiflora incarnata Linn. instreptozotocininduced diabetes in mice. J Ethnopharmacol 139(3): 801-806.

Your next submission with Juniper Publishers will reach you the below assets

- Quality Editorial service

- Swift Peer Review

- Reprints availability

- E-prints Service

- Manuscript Podcast for convenient understanding

- Global attainment for your research

- Manuscript accessibility in different formats

( Pdf, E-pub, Full Text, Audio)

- Unceasing customer service

Track the below URL for one-step submission

https://juniperpublishers.com/online-submission.php 